\title{
Sezai Karakoç’ta Poetik Düşüncenin Mantığı
}

\author{
Hülya Altunya \\ Süleyman Demirel Üniversitesi Ilahiyat Fakültesi Mantık Anabilim Dalı
}

\begin{abstract}
Özet
Şairler, kavramlarla düşünüp söz söyleyen bilim adamlarının aksine imgelerin hayat bulduğu estetik bir dilde söz söylerler. Kavramsal düşüncenin mantı̆̆ı, varlık düzenine uyumu, kendi içinde tutarlılığı ve ispatlanabilir olmayı kendine temel prensip olarak almıșken, poetik düșüncenin mantığı, bahsedilen tüm prensiplerden uzak olarak varlığı ve hakikati hissettiği biçimde anlatmayı kendine amaç edinmiștir. Buna göre günümüz şairlerinden Sezai Karakoç'un poetik mantığını anlamaya ve tahlil etmeye çalıșacağız. Onun Küçük Na’t isimli şiirinde geçen şu beyit ise bu araștırmanın odağında yer alacaktır: "Aklım yeni bir akıldır çiçeklerden / Mantığım mantığın üstünde yeni."

Burada şair, yeni bir düșünme tarzını veya yeni bir mantığı keșfetme çabası içinde olduğunu ifade etmektedir. Kendisinin "Diriliș" sözüyle formülleștirdiği bu yeni mantık, varolan tüm düșünme tarzlarının ölümünden sonra hayat bulan yeni bir "canlanma" düșüncesi üzerine kuruludur. Karakoç’un yeni mantığı, eski mantıklara göre daha açık ve daha aktif yapıdadır. Adeta onun poetik düșüncesinde her şiir, kendi mantı̆̆ıyla var olmaktadır. Yani her şiir, kendi özel mantığını doğurmaktadır. Buna göre Karakoç’un bahsettiği yeni mantık, tek, sabitlenmiș, tespit edilebilir bir düșünme biçimi değildir. Ancak bu düșünme biçiminin kendisiyle çelișen, tutarsız veya tümüyle gerçeküstü bir yapıda ortaya çıktığı da söylenemez. İste bu çalıșmada, Sezai Karakoç’un șiirlerinde dile getirdiği “yeni mantık”ını, kavramsal düșüncenin geliștirdiği mantıkla kıyaslayarak incelemeye çalıșacağız.
\end{abstract}

Anahtar Sözcükler: Sezai Karakoç, Şiir, Poetik Mantık, Klasik Mantık

\section{The Logic of Poetic Thought in Sezai Karakoç}

\begin{abstract}
Poets speak in the language of aesthetics in which the images have come to life, which contrry to the scientists who think and speak with concepts. While the logic of conceptual thinking has taken the compliance with the order of things, self-consistency and being provable as the basic principles; the logic of poetic thinking has aimed to describe the existence and truth apart from all of the pre-mentioned principles. Keeping this in mind, we will try to analyze and understand the logic of poetic thoughts of Sezai Karakoç who is one of the pioneering poets of today. The following couplet in his poem titled "Little Na't" will take place in the focus of this research: "My reason is a new reason of flowers / My logic is the new one above logic." Here, the poet expresses his endeavor to discover a new way of thinking or a new type of logic. This new logic, which he himself has formulated with the word "Resurrection/Dirilis", is based on the idea of a new "revival" that comes to life after the death of all existing modes of thinking. New logic of Karakoç is clearer and more active than the classic logic. In fact, in his poetic thought, every poem exists by its own logic. In other words, every poem gives birth to its own special logic. Accordingly, the new logic that Karakoç brought about is not a single, fixed, and detectable thinking manner. However, it cannot be concluded that this way of thinking has emerged in a contradictory, inconsistent, or entirely surreal manner. In this paper, we will try to examine the "new logic" of Sezai Karakoç expressed in his poetry, by comparing it with the logic developed by the conceptual thinking.
\end{abstract}

Keywords: Logic, Poetic Thought, Sezai Karakoç, Language, Concepts.

\section{Giriș}

Şiirsel düşünme biçimi, imgelerin ve edebi sanatların etkin şekilde kullanıldığı dilde ortaya çıkmasına karşın, kavramsal düşünme biçimi nesnesiyle mutabık olduğu

*Yazışma Adresi / Address for Correspondence: Hülya Altunya, Email: hulyaaltunya@sdu.edu.tr

Geliş Tarihi / Received Date: 28.07.2018

Kabul Tarihi / Accepted Date: 31.07.2018

Doi: $10.26701 /$ uad. 449005 düşünülen sözcüklerin kullanıldığı literal bir dilde ortaya çıkar. Zira kavramsal düşüncenin mantığında, nesnelerin yer aldığı varlık düzenine uyum kadar dilde ifade edilen ispatlamaların tutarlılığı, geçerliliği ve sağlamlığı önem arz etmektedir. Ancak poetik düşüncenin mantığında, varlığın ve hakikatin sanatçı tarafından hissedildiği biçimde dilde anlatılması söz konusudur. Günümüz şairlerinden Sezai Karakoç, klasik şiirin poetik mantığından farklı olarak yeni şiirin poetik mantığının bulunduğunu ve bu mantığın genel mantıktan kopmasına rağmen temelde onunla ilişkisini devam ettirdiğini öne 
sürer. Bu çalışmada "poetik mantık" olarak adlandırılan şiir mantığının neliği ve onun şiirinde bu mantığın nasıl kullanıldığı tespit edilmeye çalışılacaktır. Özellikle onun Küçük Na't isimli şiirinde geçen şu beyit göz önünde bulundurularak, poetik mantığın klasik mantıktan ayrıldığ ve onu sanat açısından özgün kılan tarafları soruşturulacaktır:

\section{"Aklım yeni bir akıldır çiçeklerden / Mantığım mantı̆̆ın üstünde yeni."}

Burada şu sorular eşliğinde yukarıdaki beyit tahlil edilecektir: Acaba şair, şiirinde kavramsal düşünmeden yahut diğer şairlerin düşünme biçiminden farklı olarak yeni bir mantık mı keşfetmektedir? Şair, medeniyet teorisi bağlamında formülleştirdiği ve medeniyetin yeniden canlandırılması anlamında kullandığı "Diriliş" düşüncesine benzer şekilde, daha önceki düşünme biçimlerinin hayatiyetini kaybetmesi nedeniyle onların canlandırılması anlamında bir yeni mantıktan mı söz etmektedir? Bu yeni poetik mantığın eski mantıklardan daha açık ve daha aktif olduğunu iddia eden Karakoç, acaba tek anlamlı bir düşünme biçiminden değil de, çok anlamlılığa izin veren bir düşünme ve anlama yani açık uçlu bir düşünme modelinden mi bahsetmektedir? Bu durumda Sezai Karakoç'un poetik düşüncesinde üretilen poetik mantığını, Aydınlanma düşüncesine veya akılcı felsefelere karşı çıkan romantik bir düşünme biçimi olarak kabul edebilir miyiz? İşte bu çalıșmada, Sezai Karakoç'un şiirlerinde dile getirdiği "yeni mantık"1nı, kavramsal düşüncenin geliştirdiği mantıkla kıyaslayarak incelemeye çalışacağız.

\section{2. ŞiíRIN TANIMI}

Şiirin tanımını sorgulamak sadece edebiyat kuramcılarının, mantıkçıların veya felsefecilerin değil, -belki de en başta-, şairlerin işidir. Her tanım da, şiirin hakikatle ilişkisini bir yönüyle dile getirir şekilde yapılır. ${ }^{2}$ Bu durumda ilk olarak Sezai Karakoç'un poetik düşüncesinde "Şiir nedir veya şiirin mahiyeti nedir?" sorularına cevap arayacağız. Ona göre şiir, varlığın, varoluşun anlaşılması ve anlatılması görevini üstlenen bir tür estetik araçtır. Daha açık bir ifadeyle şiir, bir taraftan fizik evrene alışmaya çalışan diğer taraftan ise metafizik evrene yönelen şairin, kavramsal düşünmeyle ilerlemeye çalışan nesir yazarından farklı olarak, imgelerle ve edebi sanatlarla süslediği dilinde, duygu ve düşüncelerini damıtarak ifade ettiği nazım türüdür. Bütünüyle dilsel ve metinsel yapısı bakımından nesirden farklı olan nazım, nesir gibi ispatlanabilir ve doğruluğu denetlenebilir bir metin tarzı da değildir. Ancak yine de şiir, nesir yani düz yazı gibi kendinde bir mantık içerir. Her ne kadar "şiir mantığı", "düz yazı mantığı” yla başlasa veya en az onun kadar olsa da, şiir mantığı, kendi şiirsel yapısını işleterek düz yazı mantığını aşar. Üstelik herhangi bir anlama sahip olmayan ifadele-

${ }^{1}$ Sezai Karakoç, Gün Doğmadan, Diriliş Yayınları, 12. Baskı, İstanbul, 2012, s. 119.

${ }^{2}$ Hülya Altunya, Klasik Mantık Açısından Hakikat ve Şiir, Büyüyen Ay Yayınları, 1. Baskı, İstanbul, 2014, s. 170. rin kullanıldığı "yeni şiir" denilen ve klasik şiirden farklı olan şiir türünde bile, şiir bütünüyle anlamsız olamaz yani kendinde bir mantığa sahiptir. Açıkçası şiir, çok farklı mantıklarla yazılmış olsa da, tüm mantıklar genel mantıktan çıkmış olduğu için her şiirin mantığının olduğu söylenebilir. ${ }^{3}$ Böylece şairimiz şiiri, -ister klasik şiir isterse de "yeni şiir" olsun-, mantıksal bir düşünme biçimine sahip olan metin türü, şeklinde tanımlayarak şiirin yapısal formu ne olursa olsun mutlaka mantık sınırları içerisinde kaldığını öne sürer.

$\mathrm{Bu}$ bağlamda Karakoç, şiirin tanımına yani mahiyetine, şiirin dilsel yapısı, estetik hazzı ve hepsinden önemlisi hakikatle ilişkisini ilave eder. Aslında hem şiirin dilsel yapısı hem de onun hakikatle olan bağı, şiirin poetik mantığıyla yakın ilişki içindedir. Çünkü dilde tezahür eden düşünce, dilin çok anlamlılığına sınır koyarak yani kasd edilen anlamın sınırlarını çizerek belirgin hale gelir. Öte yandan onun poetik düşüncesinde şiir, hakikati dile getiren veya hakikatin vücud bulduğu biricik varlık tarzıdır. Yani şiir, hakikatin derisi farz edilerek yüzülüp firlatılıp atılacak bir şey değildir. Aksine şiiri, çıkarılıp atıldığında insanı hayattan mahrum bırakacak olan hakikatin kalbi olarak niteleyen Karakoç, şiirin varlığını, insanın varlığına bağlar. "Şiir, hakikatın, doğa ve tarih içinde atan nabzı, çarpan yüreğidir."4 Öyleki yazı ortadan kalksa bile, medeniyet var oldukça söz, şiirsel dilde ifade edilmeye devam edecektir. Buna göre şiirin mahiyetini yani değişmez özünü oluşturan şey; onun yazılı olması değil, şairin hakikatle olan irtibatı ve bu hakikati doğru düşünme biçimiyle veya mantıkla dile getirmesidir.

Ne var ki hakikatin şiirde dile getirilmesi, onun, bilimsel eserlerde olduğu gibi tekrarlanabilmesine imkan vermez. Şiir, biricik ve tek olarak bulunan ve tecrübe edilen bir anda şairin dilinden akan sözcükler bütünüdür. Yaşanan bu tecrübenin daha sonra tekrarı yoktur. Burada Karakoç şairin, şiirini, bir evin yapımını tasarlayan mimar gibi değil, yaşadığı özel hallerle Tanrı́nın yaratışına benzer bir yaratışla şiirini ortaya koyan olduğunu ileri sürer. ${ }^{5}$ Şiir tam bir bilinçlilik halinin ürünü değil, adeta fizik ve metafizik evren arasında bir yerde bulunan şairin dilinden kopup gelen sözlerden ibarettir. Fakat şair, bir mimar gibi eserini tasarlamaz veya bir heykeltraş gibi bir takım duyguları taşa yontup şekle sokmaya çalışmaz. Şiir, okurunu, bir taraftan yüksek metafizik firınlara sokup çıkartırken diğer taraftan bulutsuz ve sakin ortamlarda heyecanla dolaştırır. ${ }^{6}$ Işte mantıksal düşünme biçiminde her ne kadar kavramların, kelimelerin ve anlamların tasarlanması ve belli bir sistem içinde ifade edilme zorunluluğu olsa da, şairi, bu boyutta sınırlayan bir kurallar dizgesi mevcut değildir. Ancak şairin, yaşanan bir coşku anında şiirini söylemesi, onun mantıksal bir kaygı taşımadığı anlamına da gelmez. Zira şair, şiirin anlam boyutu ihmal edildiğin-

\footnotetext{
${ }^{3}$ Sezai Karakoç, Edebiyat Yazıları I, Diriliş Yayınları, 5. Baskı, İstanbul, 2012, s. 82.

${ }^{4}$ Sezai Karakoç, Edebiyat Yazıları I, s. 122

${ }^{5}$ Sezai Karakoç, Edebiyat Yazıları I, s. 13.

${ }^{6}$ Sezai Karakoç, Edebiyat Yazıları II, Diriliş Yayınları, 4. Baskı, İstanbul, 2012, 45.
} 
de, okurun, anlamsız ifadelerin yer aldığı bir eseri anlayabilmek için çaba sarfetmeyeceğinin farkındadır. Şu halde hem şairin duygularını dile getirmesinde hem de okurun bu dile dökülen duygulara ulaşabilmesinde şiirin anlamlı bir yapıda olması gerektiği söylenebilir.

Öte yandan şiir anlayışını genel sanat anlayışıyla ilişkilendiren Karakoç şiiri, sadece şiir olarak ele almaz:

"Sanat tutumum, genel dünya görüşümün bir bölümünden başka bir șey değildir. Onu bir sesin, yeni bir sesin sirtına yüklemekten ibarettir. Benim șiirim, aşk, hürriyet, yaşayış ve ölüm gibi varolmanın dinamitlendiği noktalardaki trajik espriyi, irrasyonele ve absurde bulanmış (MUTLAK)a zaptetmektir"?

Burada şairin sanata bakışının dünya görüşünden ayrı değil, aksine birbirlerini tamamlayarak bir bütün oluşturması, hakikat ile hayal arasındaki gerilimin problem oluşturmayacak şekilde kurulmasıyla ilişkilidir. Açıkçası Platon'un İyi'lerin dünyasından kovduğu efsanelerle dolu şiir, hakikat ile arasındaki gerilimi kavramsal düzeyde muhafaza edemediği içindir. Buna karşllık Karakoç, yeni ve açık bir düşünme biçimiyle, imge ve kavramları genel dünya görüşünden koparmamakla, Platon'un sakındırdığı şiir tarzından uzak kalmıștır. Şu halde sanat eserinin fizikten kurtulup metafiziğe geçmeye çalışırken ileri atılan bir köprü ucu olduğu söylenebilir. Bu köprü ucu, her zaman metafiziğe tutunamaz. Bu durumda fiziğe geri dönen sanat eseri yere düşüp parçalanır. ${ }^{8}$ Bunun için şair, fizik ve metafizik arasındaki gerilimi problemli hale getirmedn şiirini yazmaya çalışmalıdır.

\section{3. ȘAIRIN NITELIKLERI}

Bu durumda şiirin yaratıcısı olarak şairin veya daha genel anlamda sanatçının nasıl bir düşünme biçimiyle eserini ürettiğini, onun, ne tür özellikler taşıyan biri olduğunu sorabiliriz. Acaba şair, bir peygamber gibi Tanrı'dan ilham alan ve bu ilham ile söz söyleyen midir? Yoksa şair, bir filozof veya bir mimar gibi eserini, tam bir bilinçlilikle düşünen, kurgulayan ve nesnellik kaygısı güderek herkes tarafından aynı şekilde anlaşılmaya çalışan mıdır? Karakoç şairi veya genel olarak sanatçıyı şöyle betimler:

"Sanatçı, adeta, bilmediğimiz bir dünyadan, bir kaza sonucu, dünyamıza düşmüş bir yaratıktır. Yani fizikötesi yaşantıll bir kazazede....Ișsi gücü, bu yabancilığı gidermeye çalışmak olacaktır sanatçııın öyleyse. Bazılarının sandığ ya da iddia ettiği gibi, o, yabancılaşmamış, yabancılaştırılmamıștır. Düpedüz yabancıdır o. Ona düşen, bu yabancılığı ortadan kaldırmak, șu dünyaya alışmaktır."

Şu halde sanatçı bu dünya düzeninin sınırları içinde kalan biri değildir. Aksine o, metafizik bir evrende var olmuş ancak bir kaza neticesinde bu dünyanın içine dahil olmuştur. Burada Karakoç, ne varoluşçular gibi insanın

\footnotetext{
${ }^{7}$ Sezai Karakoç, Edebiyat Yazıları II, s. 44

${ }^{8}$ Sezai Karakoç, Edebiyat Yazıları I, s. 26.

${ }^{9}$ Sezai Karakoç, Edebiyat Yazıları I, s. 23.
}

bu dünyaya atılmasından ve bu nedenle de kendini yabancı hissetmesinden ne de modern dönemin bireyinin kendine ve topluma yabancılaşmasından söz ediyor. Ona göre sanatçı, bir tür peygamber gibi yeteneklerini ve ilhamını Tanrı'dan almış ancak peygamber gibi bir mesaj iletmek üzere görevlendirilmemiş kişidir. Dolayısıyla şairin toplum için üstlendiği bir görevi bulunmamaktadır. Fakat şiirde, dini, toplumsal veya ahlaki değerlerin dile getirilmesine engel bir durum da yoktur. Böylece sanatçı metafizik evrene ait ama bu evrene alışmaya çalıșan biri olarak yani bir yabancı olarak şiirini söylemeye devam edecektir.

Gelinen bu noktada sanatçının Tanrı́yla olan irtibatı ve bu irtibatın onun düşünme biçimine etkisi üzerinde durabiliriz. Eğer sanatçı metafizik evrenden bir kaza sonucu bu dünyaya düşmüş ve bu dünyanın yabancısı ise onun, geldiği evrendeki düşünme biçimiyle eser ürettiğini söylememiz gerekecektir. Ona göre bunun için sanatçının, Tanrı’nın önünde, tam bir teslimiyet içinde alçakgönüllü bir vaziyette durması ve O'ndan bilgi alabilmek için çabalaması lazımdır. Çünkü sanatçı, Tanrı'nın yarattığı eserleri değil, yaratışını taklid ederek, bu eylemin neticesinde orjinal bir eser oluşturacaktır. Doğanın tüm sırlarının anahtarları Tanrı'dadır ama sanatçı çabalayarak doğrudan veya dolaylı olarak Tanrı'nın elindeki anahtarların bazılarına ulaşır ve eserinde bunları kullanır. ${ }^{10}$ Burada Karakoç'un bahsettiği şair, Türk edebiyatında bir çok sanatçıyı da etkilemiş olan, Eski Yunan mitolojisinde sözü edilen Prometheus'u hatırlatmaktadır. Tanrilar soyundan gelen ve isminin anlamı "öngörüsü açık" olan Prometheus, tanrı Zeus ile ölümlü insanlar hakkında çatışır ve her defasında Zeus'u kandırarak insanların yanında yer alır. En son Zeus'un elinde bulunan ve insanların ilerlemesini sağlayacak olan "ateş"i çalarak, ölümlülere verince Zeus tarafından cezalandırılır ve ölümlü bir varlığa dönüştürülür. ${ }^{11}$ İște ötelerden gelen veya kazazede olan sanatçı, Tanrı'nın elinde bulunan doğaya yönelik bazı sırları, ele geçirmeye çalışarak insanlara medeniyet kurmalarını sağlayacak bilgiyi verecektir. Ne var ki Karakoç'un sanatçısı, doğanın kendisine teslim olması veya direncinin kırılması için alçakgönüllülükle Tanrı'ya teslim olmak zorundadır.

Burada şairin yaratıcı bir düşünme biçimiyle eserlerini ortaya koyması, acaba tam anlamıyla bilinçli ve iradesine hakim olarak mı gerçekleşmektedir, sorusunu sorabiliriz. Daha açık bir ifadeyle şair, soyutlama yapıp, imgeleri ve kelimeleri düzenlerken nasıl bir düşünme biçimini kullanmaktadır? Sezai Karakoç sanatçının eserini nasıl ve hangi aşamalardan geçerek ortaya koyduğunu empirik, psikolojik, sosyolojik vb. birikimleriyle ilişkilendirerek açıklar. Buna göre üç aşamadan veya üç kattan bahsedebiliriz: Sanatçı birinci realite katında tabiattan dolaysız olarak derlediği malzemeyi işler. İkinci realite katında ise tarihin toplum hazinesinde biriktirdiği din, felsefe, bilim, düșünce, ideolojiler, eylemler, sanat eserleri, vahiy vb.

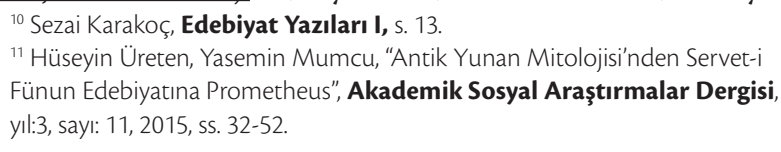


birikimlerini yani başkalarının dış realitelerini içselleştirerek kullanır. Açıkçası sanatçının yaratışa özenmesi bu iki realite katını kullanmasına neden olur. Üçüncü kat ise sanat eserini verme aşamasıdır. Teoride birbirinden ayrı ve aşamalı görünen bu katlar, aslında birlikte ve içiçedir. Üçüncü merhaleden sonra yani sanat eserini verdikten sonra sanatçı, kendi eserinden dışsallaşır yani kendinden ayrı bir realite olarak eser var olur. ${ }^{12}$ Şu halde sanatçının düşünme biçimi, her ne kadar kendisi metafizik kökenli olsa ve yine ona yönelse de, tabiatın bilgisini kendisine temel almaktadır. Başka bir deyişle fizik evrendeki tecrübeler, düşünmeye zemin hazırlamaktadır. Bunun üzerine ise sanatçının toplumdan biriktirdiği her türlü bilimsel ve felsefi bilgiler, onun düşünme biçimini oluşturmak üzere eklenmektedir. Yani sanatçının dıș ve iç tecrübeleri, sanat eserinin oluşumundaki düşünme biçimini belirlemektedir.

Bu durumda şairin şiirini dile getirebilmesi için birinci realite katında doğayı dolaysız olarak algılamasının ne anlama geldiğini sorabiliriz. Acaba şair, tekillerden hareketle tümel kavramlara ulaşan mantıkçı veya filozof gibi soyutlamalar yapmaya mı yönelmektedir? Şairin, doğayı olduğu gibi aktarmaması, aksine soyutlamalarla ve sembolik bir dilde ifade etmesi ne demektir? Kısacası şairin "soyutlama yapması" ne demektir? Karakoç'a göre "soyutlama”, doğada algılanan her şeyin (thing) şairin muhayyilesinde dönüşüme uğratılmasıdır:

“...amaç, doğayı, gerçeği öldürmek değil, ona özgürlükten bir alan açıp orada yeni bir hayatla diriltmektir. Soyutlama, burada, zorunlu bir geçiş, bir değişim, bir başkalaşım, bir metamorfoz sürecidir."13

Şu halde soyutlama denilen zihinsel etkinlik, doğanın, şairin muhayyilesinde özgürleşmesi, canlanması ve başkalaşmasıdır. Klasik mantığın tekillerden tümele giden soyutlama anlayışından farklı olan bu yaklaşımda, tekillerin değişerek yeni imgeler kazanmasından söz edilmektedir. Karakoç'a göre sanatın biçim ve kalıcılık açısından ilkesi olan soyutlama, yaratılıșın sırlarını okuyarak onları yeni bir alfabe ve dil ile ifade etme çabasıdır. Sanatta metafizik; insanüstü ve doğaüstü olanın, soyut ise zamanın ve şartların üzerindeki örtünün kaldırılmaya çalışılmasıdır. Tıpkı fotoğraf ile resim sanatı arasındaki fark da olduğu gibi bir soyutlamadan bahsedebiliriz. Ressam, doğanın deneylenen tarafını soyutlayarak net bir resim elde eder. Fotoğrafçı ise makinesini ressamın fırçası gibi kullanabilirse, soyutlama yapıp ressama yaklaşabilir. Soyutlanan doğa, sanatçının elinde ölü bir nesneye dönüşür. Eğer sanatçı kendi ruhundan bir ruh üfleyebilirse sanat eseri oluşur. ${ }^{14}$ Burada Karakoç, insan aklının doğaya bakarak soyutlama yapıp tümel kavramlara ulaşması gibi sanatçının soyutlamayla imgelerini oluşturup sanat eserinin malzemesini temin etmesini bekler. Doğadan soyutlama yoluyla üre-

\footnotetext{
${ }^{12}$ Sezai Karakoç, Edebiyat Yazıları l, s. 36-39.

${ }^{13}$ Sezai Karakoç, Edebiyat Yazıları I, s. 15.

${ }^{14}$ Sezai Karakoç, Edebiyat Yazıları I, s. 12.
}

tilen malzemeye, sanatçının ruhunun katılmasıyla ortaya çıkan eser, yeni, canlı, somut bir varlıktır. Aynı şekilde kavramsal düşünme biçiminde, doğadan soyutlamayla elde edilen kavramlar, mantığın kurallarına uyularak yapılan akılyürütmelerinde argümanlar, ispatlar veya kanıtlar nesnel olarak ortaya çıkar. Ancak mantıksal düşünmenin yöntem olarak kullanıldığı bilimsel eserlerde nesnellik iddiası söz konusu iken, sanatçının kendi ruhundan üflediği şiirinde öznellik var gibi görünmektedir.

\section{POETIK MANTIK}

Bu bağlamda hem şairin düşünme biçiminin hem de şiirin anlamının öznel mi yoksa nesnel mi olduğunu sorabiliriz. Öncelikle Sezai Karakoç, şiirde "duygu realizmi”nin olması gerektiğini yani çıplak duygu ve düşüncelerin, duyarlıktan biçimlenerek yeni bir formda eser olarak ortaya çıktığını iddia eder. Şairin psikolojik halleri, sanat eserine verdiği duygu ve düşünce, okuru tarafından benzeri bir şiddette hissedilmelidir. ${ }^{15}$ Aslında şair, duygularını olduğu gibi şiire aktardığında, bu metinde nesnellik aramak anlamlı olmayacaktır. Fakat şiir, bir yönüyle şairin duyguları tarafından yönlendirilirken diğer taraftan da dış gerçeklikle ilişkisini sürdürmektedir. Dış gerçekliğin metamorfoza uğraması, onu tümüyle gerçeküstü hale getirmez. Böylece şair, yaratılanı taklid ederek değersiz bir eser üretmek yerine "yaratıcı düşünme biçimiyle", yaratışı taklid ederek orjinal bir eser üretir. ${ }^{16}$ Daha açıkçası şair, açıktan "evet veya hayır" şeklinde tasdik edilecek veya reddedilecek yargılardan ziyade "bize dokunan" kendi dilsel ifadeleriyle șiirini var eder. ${ }^{17}$ Acaba bu orjinal eserin bir açıdan öznel başka açıdan nesnel olduğu söylenebilir mi?

Sanat eserinin varoluşunu inceleyen Sezai Karakoç, onun nesneliğini ve nesnel olarak bilinebilmesini tartışır. Şair kendi ruhundan şiire can verdiğine göre ne ölçüde şiir, nesnel olarak anlaşılmaya imkan verir? Aynı soruyu soran Heidegger de, sanat eserinin "şey/thing/ding/dingsein/ dingheit" oluşunu, "madde-form" ekseninde tartıştıktan sonra, form ve içeriğin, herhangi bir şey ve herşey için kullanılabilecek en eski kavram çifti olduğunu söyler. Buna göre "form", akli/rasyonel olanla ve madde ise akli olmayanla/irrasyonelle ilişkilidir. Akli olan mantıksal/ logical olarak alınırsa, akli olmayan/irrational mantık dışı/alogical (mantıksız/illogical değil) olarak alınır. Buna ek olarak özne-nesne ilişkisi, madde-form kavram çifti olarak eşleştirilirse, temsil, hiçbir şeyin üstesinden gelemeyeceği kavramsal makinelere hükmeder. ${ }^{18}$ Heidegger için sanatın özü; şiirdir, şiirin özünde ise hakikatin kurulması vardır. Açıkçası ona göre şiir, varolanın açıklığının dile gelmesidir. ${ }^{19}$

Şiirin öznel veya nesnel olarak anlaşılması problemini,

\footnotetext{
${ }^{15}$ Sezai Karakoç, Edebiyat Yazıları I, s. 34.

16 Sezai Karakoç, Edebiyat Yazıları I, s. 32-33.

${ }^{17}$ Martin Heidegger, Poetry, Language, Thought, trans, and Int. Alfred Hofstadter, HarperCollins Publishers, Newyork, 2001, s. 123-125.

${ }^{18}$ Martin Heidegger, "The Origin of The Work of Art", Basic Writings içinde, ed. David Farrell Krell, Harper/Row Publishers, New York, 1977, s. 157-158.

${ }^{19}$ Işık Eren, Sanat ve Bilgi ilişkisi, Asa Yayınları, Bursa, 2006, s. 66-67.
} 
“Tanrı'nın yaratma eyleminin taklidi” bağlamında ele alabiliriz. Sezai Karakoç, Tanrı'nın yaratma eylemini taklitten söz ederken, aslında şaire, sonsuz imkanlar içerisinden bir yol açmaya çalışmaktadır. Açıç̧ası hiçbir şey sonsuzun dışında değildir. Daha açık bir deyişle nesir yani düzyazı, okurunu belirli, sınırlı, tayin edilmiş bir hedefe yöneltirken yani sonlu bir mantığa zorlar iken, şiir, okurunu kendi içinde tutup, kendi sonsuz anlamlarına bırakmakta ve onu, sonsuzun mantığının karşısına koymaktadır. Sonsuzluk içinde akan şair, çelişkilerin var olduğu fizik evrenden çelişkilerin olmadığı metafiziğe yönelmiş olarak şiirlerini dile getirdiğinden şiirin anlam evreninde çelişki yoktur. Çünkü sonsuzda çelişki olmaz. Diğer taraftan her şiir kendi mantığını ürettiğinden başka bir şiirle kıyaslanmaz. Dolayısıyla bir şiirin anlamında çelişkinin olup olmadığını denetleyebilmek için başka bir şiire de bakılmaz. Böylece şair, sonlu fizik evreni aşarak sonsuz metafizik evrene ulaştığından, onun poetik mantığında çelişkiye yer yoktur. Yine burada adeta Şaman veya Delfi mitlerinde dile getirilen sonsuzluk düşüncesini hatırlıyoruz. Bu mitlerde sonsuz, bir kıvılcım şeklinde şiirde parıldar ve bu kıvılcımın nerede parıldadığını söyleyen ise mantıktır. Yani çelişkiye yer olmayan şiirin sonsuz anlamlarında bir poetik mantık gizlidir.

Karakoç'un Küçük $N a^{\prime} t$ isimli şiirinde söz ettiği “yeni mantık", kavramsal düşünceye dayanan iki değerli mantık değil, poetik düşünme biçiminin ürettiği poetik mantıktırki, bu, şiirin hem oluşum safhalarında işleyen hem de okuru tarafından da anlaşılan, aynı zamanda estetik yargıya sahip olan ve çok anlamlılığa da izin veren yapıdır. Burada klasik mantığın "logos" dediğimiz pürrasyonel yapısından ziyade sezgisel düşünme biçiminin işlediği bir yapıyı kasd ediyoruz.

Belkide Sezai Karakoç, şair için sürgünden bahsettiğinde kavramsal düşünmenin bulunduğu dünyanın sınırlarından öteye geçmeyi işaret etmektedir. Çünkü kavramsal düşünce, belli bir rasyonel zincir takip edilerek ilerleyen gidimli ve sonrası tahmin edilebilir olandır. Ancak şiirsel düşünme böyle değildir. Şair, yeni mantık dediğinde, şiirin var olan mantığın ötesine geçtiğini ima etmektedir.

Yeni şiirin yeni mantığına geçmeden önce, klasik şiir ile yeni şiir arasındaki farka değinilebilir. Klasik şiir yani eski şiir; düşünceyle başlar, kafiye ve ölçüyle dinlendirilir. Açıkçası bu şiir, belli bir düşünceyi ifade etmek üzere söylenir ve kafiye ve ölçü gibi estetik unsurlar ise haz için bulunur. Buna karşın yeni şiir, en az düşünceyle başlar ve şuuraltı, davranışlar ve benlikle inşa edilir. Bu şiir tarzını dinlendiren ise zekadır. ${ }^{20}$ Genel mantığa uygun olan eski şiir, olgun bir insana benzerken, yeni şiir idraki taze ve hür olan çocuğa benzer. Nasıl ki çocuk utanmaz, korkmaz bir şekilde konuşur, çelişkiye düşer ise yeni insan da aynı şekilde iyi niyetli olarak bu çelişkili yapının içinde yaşamakta güçlük çekmez. ${ }^{21}$ Kaçınılmaz olarak düşünce, genel mantığa uygun düzenlenen ilk unsur olduğuna göre,

${ }^{20}$ Sezai Karakoç, Edebiyat Yazıları I, s. 82.

${ }^{21}$ Sezai Karakoç, Edebiyat Yazıları I, s. 83-84. şiirin her türü ister istemez genel mantıktan çıkan bir düşünmeyi az veya çok barındırmaktadır.

Günümüz şiirinin yani yeni şiirin, yeni mantığı vardır. Bu mantık Aristo ve Kant'ın mantığı veya aklı değildir. Freud, Bergson ve W. James'ın doğuşunu hazırladıkları yeni mantık, insanı, somut olarak anlar. Klasik idrakten bir tür sapma olan bu yeni mantık, pragmatiktir ve hakikatin hayattan kopuk olduğu, bu dünyanın dışında değil, insanların kendilerinin var ettiği bir şey olduğu iddiasını öne sürmektedir. Öte yandan modern dönemde ilkel toplumlar üzerinde yapılan araştırma sonuçlarına göre, evrensel, sabit değişmeyen genel bir mantığın olmadığı sonucu ortaya çıkmıştır. Bu durumda genel mantığın evrensel olmadığı da tespit edilince şairin yeni mantığı genel mantığı aşan bir güçle behaviyorist davranışa paralel bir yönde gelişmiştir. Yeni şiirde, şair, saçmalama dahil, "anlam dışı” olsun veya olmasın tüm anlam çeşitlerini aktif olarak kullanabilir. Şair gelen her şiirinde, mantık karşısında açık ve aktif olarak kendi şiir mantığını üretir yani her şiirin kendi mantığı vardır. ${ }^{22}$ Denilebilirki günümüz şiirinin, şairin duygu ve düşünceleri ekseninde birbirinden farklı poetik mantıkları bulunmaktadır.

Sezai Karakoç'un poetik mantığı, şiirin anlaşılmasında kavramsal düşünmeden yardım alır mı? Şiirin anlaşılmasında "gösteren-gösterilen", "zahir-batın", "delalet yolları" gibi söz-anlam ilişkisini tayin eden yöntemler kullanılır mı? Acaba onun şiir kuramı bağlamında düşünüldüğünde, mistik veya tasavvufi bir anlamdan mı yoksa kavramsal düşüncenin kabul ettiği şekilde özlerin varlığı kabulü üzerine inşa edilmiş olan birebir tespit edilebilir anlamlardan mı söz edeceğiz? Yani Sezai Karakoç'un anlama bakışı, realist mi, idealist mi, pozitivist mi yoksa mistik midir? Onun poetik mantığında anlamın, tek bir yöntemle tespitinin mümkün olmadığını söyleyebiliriz. Sözgelimi o, Yunus Emre'nin şiirlerinde batıni anlamlara yer olmadığını ve şiirin kasd ettiği anlamın, şiirin bütünü içinden çekip çıkartmanın mümkün olduğunu ileri sürer. Şiirin okuru tarafından tespit edilebilir bir anlamı mevcut olduğu için Yunus Emre'nin şiirinde semboller çıplaklaştırllarak arkalarındaki realist anlamlara ulaşılır. ${ }^{23}$ Yani şair kasdını dolaylı yoldan ifade etmesi nedeniyle okur, bu sembolleri çözerek asıl kasd edilen anlamı elde eder. Şu halde Yunus'un şiiri, düşünce merkezli şiirdir yani şair neyi söyleyeceğini önce literal olarak düşüncede kurgulayan sonra şiirsel yapıda sembolik dile aktarandır ve semboller çözüldügünde şiirin anlamına ulaşılır.

Ne var ki yeni şiir, eski şiirde olduğu gibi gösteren-gösterilen ilişkisiyle sembollerin çözüldüğü bir mantığa sahip değildir. Sezai Karakoç’a göre yeni şiirin, adeta çocuk ruhlu olan bu şiirin mantığının allak bullak olmuş gibi görünse de, dava şiirlerinden tabiat şiirlerine kadar tüm şiir türlerindeki mantıksal karmaşa sadece görünüştedir. Buna karşın eski şiirde, şiire özgü olan bir iç mantığın iş-

\footnotetext{
${ }^{22}$ Sezai Karakoç, Edebiyat Yazıları I, s. 83.

${ }^{23}$ Sezai Karakoç, Yunus Emre, Diriliş Yayınları, 16. Baskı, İstanbul, 2012, s. 25.
} 
lediğini tespit etmek daha kolaydır. ${ }^{24}$

"Aslında dil, mantık sınırlarını aşan tarihi-sosyolojik bir gerçekliktir; irrasyonelden de mantıktan olduğu kadar, oluş ve beslenişinde, gıdalanmıştır." Mitoloji, ya da iç musiki kullanımları da mantı̆̆ı şiirde kıran akış çalkantıları ve doğrultularıdır. Homeros, Firdevsi, Dante, Hafiz, Goethe, Íkbal, hep görünüşte mantığın şiirini geliştirmiş gibidirler; ama, gerçekte, şiirin iç planında, poetik mantık egemendir esere. Ve şiiri düz yazıdan ayıran da budur."25

Eğer şiirin sadece imgesi olursa veya edebi sanatlarla süslenmiş olursa ama şiirin mantığı olmazsa, şiir iç derinliğini kaybeder. Ona göre şiirin, gelecek zamandaki insanlara da bir şey söyleyebilmesi için görüntüyü, akışı, şiirin gelişimini güçlendiren imgenin arka yüzünde şiire derinlik katan şiir mantığı olmalıdır. ${ }^{26}$ Böylece poetik mantık, hem klasik şiirde hem de yeni şiirde varlığını, farklı formlarda bile olsa hissettirmeye devam edecektir.

\section{DEĞERLENDIRME VE SONUÇ}

Sezai Karakoç'un şiirinin esas özü, lirizm, poetik akış, insan psikolojsini derinden ve kalıcı yanından izleme olmakla birlikte, Tanrı önünde samimi yaşam ve şahsi deneyim sahibi olma da vardır. Bu yüzden metafizik bir evrenden seslendiğini, “... ben öteliyim..." ${ }^{27}$ şeklinde ifade ederken Karakoç, bir yandan metafizik kavramları tasavvufi mahiyette kullanmış olmasıyla mistik bir tavır sergilemekte, diğer yandan şiirinin biçim olarak modern tarza uygun olmasıyla bu çağa hitap etmektedir. Bununla birlikte onun şiirine tam anlamıla ne tasavvufi şiir ne de modern şiir adlandırmasını yapabiliriz. ${ }^{28}$ Şu halde onun şiiri, klasik şiir ile modern şiir arasında orta bir noktadadir.

Onun şiirindeki poetik mantığın, akıl ile mi yoksa duygu ile mi işlediğine bakılacak olursa, tek bir vasıtadan bahsedilemez. Zira ona göre hayatı yöneten ilke, zeka, zekanın güçlenmişi ve olumsuzluklardan olanca arınmışı akıl, akıldan daha güçlü olan gönül ve bunların hepsinden daha güçlü olan ruh ${ }^{29}$ olduğu için hem şiirin oluşumunda hem de okur tarafından anlaşılmasında tüm bu aracıların rolü vardır.

Şiirin anlaşılmasına gelince, o, nesir gibi okurunu öne firlatan bir anlama biçimiyle değil, okurunu kendi içinde tutan bir yapıya sahiptir. Karakoç'un şiiri de, şairin muhayyilesinden ve iç tecrübesinden gelen sözlerin dile aktarılmasından ibaret olduğuna göre, okur, tam olarak şiirin anlamının doğruluğunu test edemez. Ancak şair kendiliğinden bildiği bir hakikat alemine okurunu götürmek için şiirini, burak olarak kullandığında, okur, bu hakikati anlar. Bu dünyaya sürgün edilen şair, şiiriyle oku-

\footnotetext{
${ }^{24}$ Sezai Karakoç, Edebiyat Yazıları I, s. 84.

25 Sezai Karakoç, Edebiyat Yazıları I, s. 84-85.

${ }^{26}$ Sezai Karakoç, Edebiyat Yazıları I, s. 86.

${ }^{27}$ Sezai Karakoç, Monna Rosa, Diriliş Yayınları, 18. Baskı, İstanbul, 2012, s. 16

${ }^{28}$ Münire Kevser Baş, Sezai Karakoç Şiirinde Metafizik Vurgu, Insan Yayın-

ları, Istanbul, 2011, s.14.

${ }^{29}$ Sezai Karakoç, Edebiyat Yazıları I, s. 9.
}

runu sürgüne götürür. Şiir hem bu dünyada hem de ötede olduğu için özne ve nesne ayırımından da söz edemeyiz. Görünüşteki bu ayırım yapaydır. Çünkü Tanrı'dan aldığı ilhamla ve Tanrı'nın yaratma eylemini taklid eden şairin bu gücü, kendinden değildir. O halde şair ve ona bu gücü veren arasında bir birlik vardır. Şairin yarattığı şiir, Plotinus'ta olduğu gibi, fizik evrendeki formların metamorfoza uğrayarak ideal formlar haline gelmesidir. Yani şairin yaratıcılığı asıl değil, izafidir. Aslında şair, akmakta olan sonsuz imkanlar arasında, Tanrı́nın verdiği gücü kullanarak şiirini ortaya koymaktadır.

Son olarak Sezai Karakoç'un şiirinde, yeni mantık klasik mantıktan farklı olarak karşımıza çıkmaktadır. Onun poetik düşüncesinde mantık, şiir ırmağının akış yatağıdır. Irmak yani şiir kendi yatağını açar. Mantık, her şiirin yatağını açmasıdır ve akmasıdır. Şiir yol alırken kendi yatağını açarak ilerler. Irmağın yatağı dümdüz olmaz. Aksine o, içinde aktığı gerçekliğin topografyasına göre hareket etme ve ona göre biçimlenmek durumundadur. Kısacası onun "poetik mantık" olarak adlandırdığı şey, hem klasik hem de yeni şiirde, şiirin iç planında, derinde var olan düşünme biçimidir.

\section{KAYNAKÇA}

Altunya, H. (2014). Klasik Mantık Açısından Hakikat ve Şiir. İstanbul: Büyüyen Ay Yayınları, 1. Baskı.

Baş, M. K. (2011). Sezai Karakoç Şiirinde Metafizik Vurgu, İstanbul: İnsan Yayınları.

Eren, I. (2006). Sanat ve Bilgi ilişkisi, Bursa: Asa Yayınları.

Heidegger, M. (1977). The Origin of The Work of Art, Basic Writings içinde, ed. David Farrell Krell. New York: Harper/Row Publishers.

Heidegger, M. (2001). Poetry, Language, Thought, trans, and Int. Alfred Hofstadter, Newyork: HarperCollins Publishers.

Karakoç, S. (2012a). Edebiyat Yazıları I, İstanbul: Diriliş Yazıları. 5. Baskı.

Karakoç, S. (2012b). Edebiyat Yazıları II. İstanbul: Diriliş Yayınları, 4. Baskı.

Karakoç, S. (2012c). Yunus Emre. İstanbul: Diriliş Yayınları, 16. Baskı, İstanbul, 2012.

Karakoç, S. (2012d). Gün Doğmadan. İstanbul: Diriliş Yayınları, 12. Baskı.

Karakoç, S. (2012e). Monna Rosa. İstanbul: Diriliş Yayınları, 18. Baskı.

Üreten, H., Mumcu, Y. (2015). Antik Yunan Mitolojisi'nden Servet-i Fünun Edebiyatına Prometheus. Akademik Sosyal Araştırmalar Dergisi, 3(11), 32-52. 